\title{
Interactions Between the Nematode Parasite of Pigs, Ascaris suum, and the Earthworm Aporrectodea longa
}

\author{
By H.-O. Kraglund ${ }^{1,2}$, J. Grønvold ${ }^{2}$, A. Roepstorff ${ }^{1}$ and H. Rawat ${ }^{2}$ \\ ${ }^{1}$ Danısh Centre for Experımental Parasıtology, ${ }^{2}$ Zoology Sectıon, The Royal Veterınary and Agrıcultural Unı- \\ versity, Frederiksberg, Denmark.
}

\begin{abstract}
Kraglund H-O, Gronvold J, Roepstorff A, Rawat H: Interaction between the nematode parasite of pigs, Ascarid suum, and the earthworm, Aporrectodea longa. Acta vet. scand. 1998, 39, 453-460. - Pig faeces in which Ascaris suum eggs had been embryonatıng for 57 days were placed in buckets of soll containıng either 30 or no earthworms (Aporrectodea longa). When present, earthworms consumed the faeces and transported the eggs down into the soll, without inflicting any visible damage on the eggs. In later experıments 10 earthworms from the above experiment were fed to each of ten pigs, and another 40 earthworms were dissected. None of the 10 pigs became infected with $A$ suum through consumption of earthworms, and none of the dissected earthworms were found to contain $A$ suum larvae This experiment indicates that $A$ longa did not act as a paratenic host for $A$ suum but shows that earthworms are very efficient in transportıng $A$ suum eggs from faeces deposited on the soil surface into the soll
\end{abstract}

\section{Introduction}

An increasing number of outdoor pig herds are being established in Denmark, and therefore there is a need for more knowledge of transmission patterns of pig helminths on pastures. Earthworms are known to be important in the disappearance of cattle dung on Danish pastures (Holter 1979) and similarly they seem to remove much pig faeces (Larsen 1996). Therefore, earthworms may be in direct contact with the eggs and larvae of many pig helminths.

Szelagiewicz-Czosnek (1972) found that earthworms of the species Lumbricus terrestris collected from pig-pastures or force-fed with infective eggs of Ascaris suum may contain $A$. suum larvae in the body cavity. Furthermore,
Szelagiewicz-Czosnek was able to infect guinea pigs with $A$. suum by feeding them with force fed earthworms. These findings may be important for the understanding of the epidemiology of $A$. suum in outdoor-reared pigs.

The most common earthworm on the pastures of the experımental farm of the Royal Veterinary and Agricultural University is Aporrectodea longa. The objective of this study was to elucidate whether the rather thick-shelled eggs of $A$. suum are destroyed when passing through the digestive tract of $A$. longa, i.e., whether they simply pass through the earthworm, or whether they hatch and establish in the earthworm, and to investigate the possibility that $A$. longa may then act as a paratenic host for $A$. suum. 


\section{Materials and methods}

Experimental principle

Pig faeces containing embryonated $A$. suum eggs were placed in buckets containing soil without earthworms or with 30 earthworms. Three weeks later soil, faeces and earthworms were examined for A. suum eggs and larvae, and earthworms were fed to pigs which 1 or 2 weeks later were examined for $A$. suum larvae.

\section{Experimental design}

Soil (approx. $70 \%$ organic matter in dry soil) and earthworms were collected from the experimental farm of the University $20 \mathrm{~km}$ west of Copenhagen. The soil was sieved $(10 \mathrm{~mm}$ mesh) and macroscopically visible earthworms and earthworm cocoons were removed. Fresh pig faeces containing $A$. suum eggs were mixed thoroughly. Portions of $100 \mathrm{~g}$ of faeces were kept moist and stored for 57 days at $18-22^{\circ} \mathrm{C}$, at which time the eggs contained slender motile larvae. One portion of faeces was then deposited on the soil surface of each of 10 buckets (height $20 \mathrm{~cm}$, diameter $27 \mathrm{~cm}$ ) each containing approx. $8.8 \mathrm{~kg}$ soil (density $1.0 \mathrm{~g} / \mathrm{ml}$ ) (Fig. 1). Two days prior to deposition of the stored faeces, $30 \mathrm{~A}$. long $\mathrm{a}$ were added to each of 6 buckets. The 4 remaining buckets served as controls. The buckets were covered with lids and aerated for 15 min every 2-3 days. No water was applied during this part of the experiment.

\section{Soil samples}

Three weeks post-deposition, the soil of each bucket was separated into a centre (diameter 10 $\mathrm{cm}$ ) and a peripheral fraction (width $8.5 \mathrm{~cm}$ ) in each of 3 levels (depths: $0-4,4-8$ and $8-15 \mathrm{~cm}$ ) (Fig. 1). After weighing and mixing, eggs were counted in subsamples of each soil fraction by a floatation method which was a slight modification of the method originally described by Larsen (1996). Using 10 gram samples and 4 successive extractions, Larsen (1996) found his method to have an average recovery of $82 \%$.In the present modification we used 2.5 gram samples and 2 successive extractions of each sample. No significant difference was found ( $t$-test; $p>0.05$ ) in comparison with the efficiencies of the 2 methods on soil from the present study.

\section{Faecal samples}

The concentration of $A$. suum eggs per gram fresh pig faeces (EPG) was determined with a McMaster method (Roepstorff \& Nansen, in press) in which a suspension of faeces in water was sieved and spun down, the sediment resuspended in floatation fluid (saturated $\mathrm{NaCl}$ with $500 \mathrm{~g}$ of glucose per l) and counted in a traditional McMaster counting chamber. However, it appeared that the efficiency of this method was relatively low when used on old faeces. Therefore, the EPG in old faeces was determined by repeating the whole procedure on the faecal matter retained by the sieve. On one occasion all steps were repeated 5 times to estimate the efficiency.

\section{Examination of earthworms}

At dissection of 40 earthworms the coelomic fluid, brown bodies, nephridia, intestinal tract, body wall, seminal vesicles, calciferous glands, blood vessels, and hearts were examined microscopically (50×) for $A$. suum larvae. Thereafter the organs were left in $0.9 \% \mathrm{NaCl}$ at room temperature for $24 \mathrm{~h}$ and the microscopical examination was repeated.

Observation of $A$. suum eggs in earthworm excrements

In a non-quantitative experiment, 6 adult $A$. longa were placed in a plastic box $(5 \times 7.5 \times 12$ $\mathrm{cm})$ containing $200 \mathrm{~g}$ of garden soil. Fourteen grams of pig faeces containing fresh undeveloped A. suum eggs (EPG: 200) were placed on the soil surface. After 1 week at $12^{\circ} \mathrm{C}$ when 
A
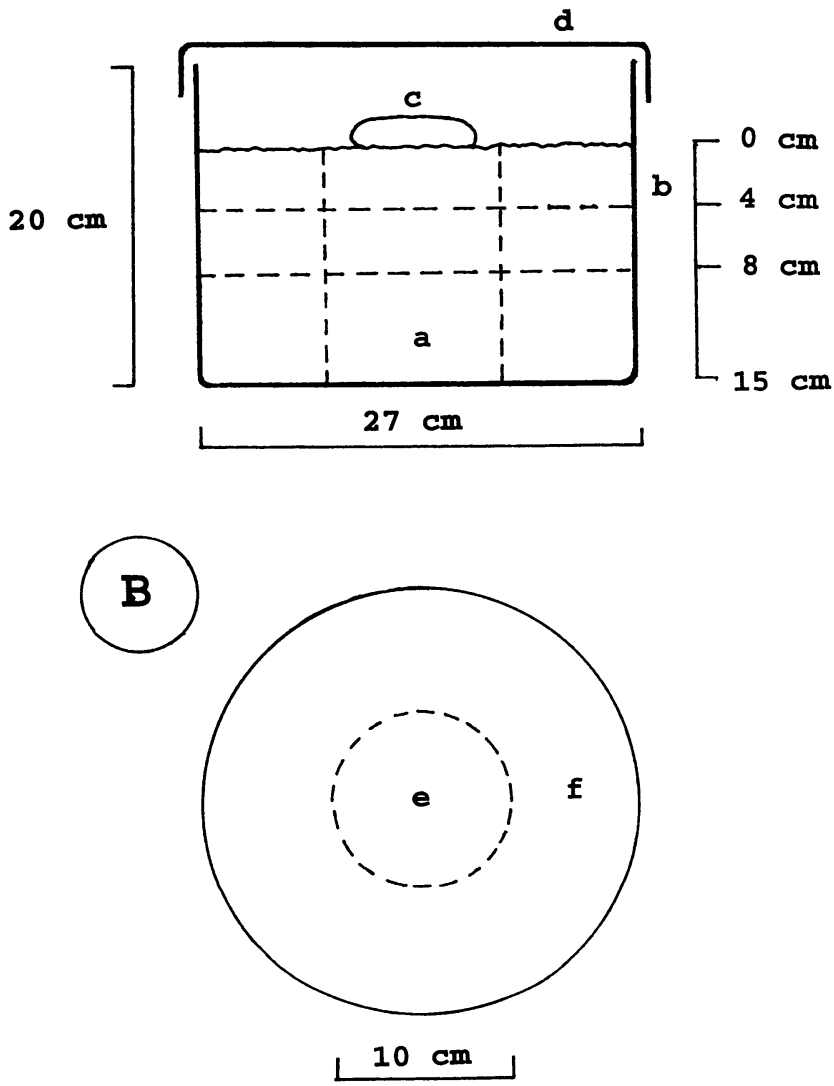

$27 \mathrm{~cm}$

Figure 1. Cross section (A) and surface view (B) of the experımental setup. a: soll; b: plastic bucket; c: 100g pig faeces The dotted lines indicate the soll compartments ( 3 horizontal layers, each divided in a central (e) and a peripheral part (f). Each compartment was analysed for A. suum eggs).

most of the faeces had been eaten, the earthworms were removed and washed 3 times in tap water and finally placed in shallow water for 24 $\mathrm{h}$ at $12^{\circ} \mathrm{C}$. During that period the earthworms defecated in the water. The water was subsequently centrifuged and the sediment was sus- pended in $1 \mathrm{~N} \mathrm{NaOH}$ for another $24 \mathrm{~h}$. Some of the sediment was suspended in floatation fluid and examined in a McMaster counting chamber, while the remaining sediment was mixed with moist vermiculite which was regularly stirred and kept moist during 2 months before 
being sieved and floated in McMaster chambers to examine egg development.

\section{Earthworms fed to pigs}

To evaluate whether the earthworms from the buckets harboured infective $A$. suum larvae within the body, earthworms were fed to parasite-free pigs. To eliminate unhatched Ascaris eggs, earthworms recovered from the buckets were left overnight in tap water to defecate. They were then washed in tap water and transferred to $A$. suum-free soll in which they were left for 2 days, then they were washed and transferred to new buckets with A. suum-free soil for another 2 days. After a final washing, 10 earthworms were hand-fed to each of 10 individually-penned pigs that had not been fed since the day before. Half the pigs ate all earthworms willingly. The other half would only eat the earthworms after the earthworms had been chopped and mixed with their regular feed.

\section{Post mortem examination of pigs}

The pigs were slaughtered 7 days (5 pigs) or 14 days ( 5 pigs) post-1nfection. In addition, 5 pigs which had not been fed earthworms served as controls and were slaughtered with the first 5 experimental pigs. In all pigs the livers, lungs and small intestines were examıned for immature $A$. suum. The livers were checked for white spots and also $A$. suum larvae were searched for in $50 \%$ of the liver tissue and all lung tissue by a macro-Baermann method (Eriksen et al.1992). The remaining $50 \%$ of the liver tissue was examined by the agar-gel method (Slotved et al. 1996). The presence of A. suum in the contents of the small intestines was checked by the agar-gel method (Slotved et al. 1997)

\section{Calculations and statistics}

The total numbers of eggs in soil and faeces were calculated from the known weights of the soil fractions and faeces portions and the num- ber of eggs extracted from subsamples of the soil and faeces. The efficiencies of the methods used were incorporated in the corrected values. Comparison of the total egg numbers of the buckets was made by an ANOVA. T-tests were used when comparıng the faecal mass and $A$. suum egg numbers in buckets with and without earthworms. Relative egg concentrations of the various soil compartments in each bucket with earthworms were calculated as percent of the mean concentration within all the soil of the bucket with the formula: (amount of eggs in compartment/weight of so1l in compartment)/ (total amount of eggs in bucket/total weight of soil in bucket) $\times 100$. A 2-way ANOVA was used for the comparison of the relative concentrations of the compartments with vertical and horizontal dispersal as independent variables. Homogeneity of variance was always confirmed by the Fmax-test when using the ANOVA or $t$-test.

\section{Results}

The first observations of faeces disappearing were made 9 days after deposition. It was observed that the faeces portions were gradually hollowed out from below. In 3 of the 6 buckets with added earthworms, all faecal matter had disappeared 3 weeks after deposition. The remaining 3 buckets contained significantly less $(p<0.05)$ faecal matter than the control buckets. Three small, presumably newly hatched, earthworms were found in each of 2 of the control buckets. The faeces portion in one of these control buckets was slightly hollowed out in one end, having lost a little of its volume.

Eggs recovered from faeces and soil had retained their protein coats and appeared normal. Moving larvae were observed inside many of the eggs.

At the start of the experiment, when the 57-dayold faeces was deposited in the buckets, 1.01 
(S.E. 0.02) million eggs were present per faeces portion. Three weeks later a total of 1.04 (S.E. 0.10 ) and 0.69 (S.E. 0.09) million eggs were recovered in soil plus faeces in buckets with and without earthworms added, respectively. Thus, the total mean egg number in the buckets with A. longa was not reduced during the 3-week period, while the total number of eggs found in the control buckets was significantly lower $(p<0.01)$ than the number of eggs at faecal deposition. Significantly more $(p<0.01)$ eggs were found in the buckets with earthworms than in the controls. Seventy-nine percent of the eggs present in the buckets with earthworms were found in the soil, whereas less than $6 \%$ of the eggs in buckets without earthworms were found in the soil.

Within the soil of the buckets with earthworms there was no significant difference $(p>0.05)$ in the relative concentration of eggs with increasing depth while there was a significantly higher $(p<0.05)$ relative concentration of eggs in the perimeter compared to the centre compartments (Table 1).

Since the extraction of eggs from faeces and soil involved 2 different methods, the results could be biassed by different efficiencies. Thus, 5 succeeding extractions on 8 samples of 57day-old faeces were done and revealed that $72 \%$ of the sum of eggs from all 5 extractions were found in the first 2 , while only $4 \%$ were present in the fifth. Therefore the efficiency of the method was assumed to be close to $72 \%$. The efficiency of the method used on soil has been estimated to be $82 \%$ (Larsen 1996). Correction for the different efficiencies of the methods did not change the distribution patterns nor the statistical relations mentioned above. Fig. 2 shows the values corrected for efficiencies of the methods.

A single white spot was found on the liver surface in each of 2 control pigs and each of 3 pigs slaughtered 2 weeks post infection. No Ascaris
Table 1 Mean (range) of the relative concentrations of eggs in each of the 6 soil compartments in buckets with eartworm $(n=6)$.

\begin{tabular}{lrc}
\hline & Periphery & Centre \\
\hline Top & $100(80-134)$ & $85(55-116)$ \\
Middle & $114(86-168)$ & $85(66-113)$ \\
Bottom & $99(66-121)$ & $82(55-125)$ \\
\hline
\end{tabular}

larvae were recovered from livers or lungs of any pig. From the contents of the small intestines $1 \mathrm{~A}$. suum larva was found in each of 2 control pigs and 1 larva was found in each of 2 experimental pigs slaughtered 2 weeks after the feeding with earthworms.

No nematodes resembling $A$. suum larvae were found in any of the 40 dissected earthworms. Nematodes of the genus Rhabditis were found in all earthworms (16-331 per earthworm). These nematodes were predominantly present in the brown bodies of the earthworms but were also present in coelomic fluid, nephridia and seminal vesicles. No other nematode genera were identified. Most of the Rhabditis nematodes were larvae. The few adult male and female Rhabditis that were present were identified to be $R$. maupasi.

Microscopical observation on earthworm excrements revealed apparently unaltered, unembryonated $A$. suum eggs indicating that at least some eggs do pass through the earthworm digestive tract intact. Furthermore, these eggs were able to embryonate when cultured later in the laboratory.

\section{Discussion}

From this study it is evident that the earthworm $A$. longa does feed on pig faeces, and that the large majority of embryonated $A$. suum eggs do not necessarily hatch or sustain obvious physical damage during the passage through the digestive tract of $A$. longa These findings agree 


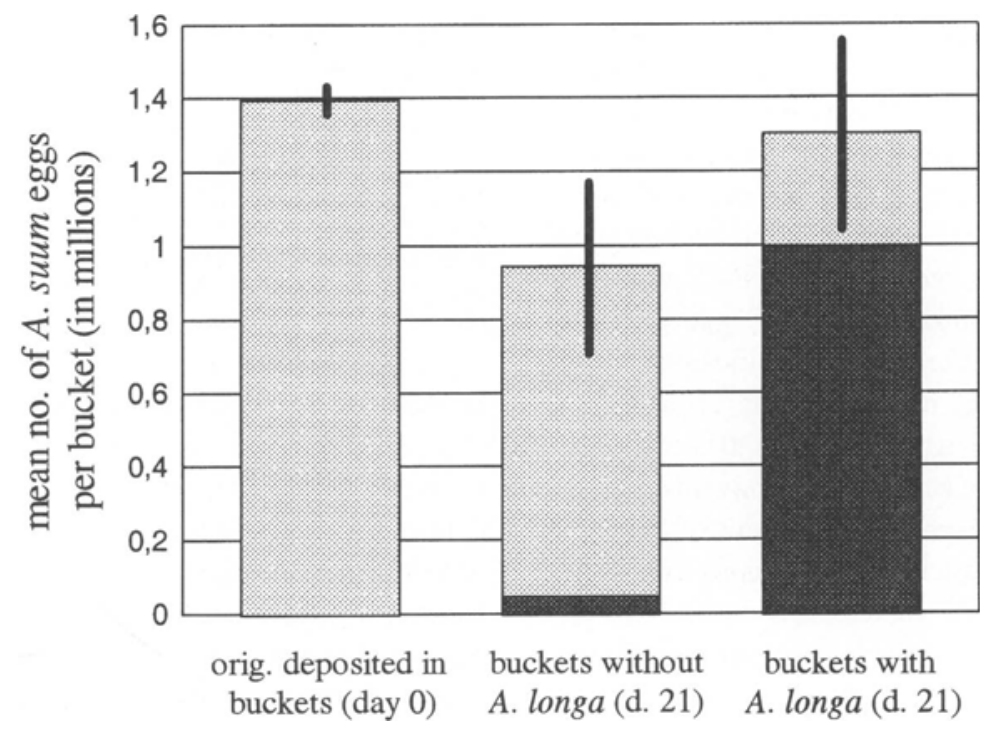

Figure 2. The effect of earthworm activity on the recovery of $A$. suum eggs using values corrected for the efficiencies of the methods (i.e. soll 82\%, faeces 72\%). The columns (from the left) show the number of $A$ suum eggs originally deposited in the buckets and the numbers of eggs 3 weeks later in buckets with and without earthworms added. Light areas: eggs in faeces. Dark areas: eggs in soil Bars show the $95 \%$ confidence interval of the mean total number of eggs recovered from the buckets.

with those of an experiment referred to by Rysavy (1969), in which eggs of A. suum, which had passed the intestine of the earthworm $L$. terrestris, were found fully capable of further development.

The reduction in the egg numbers recovered from the buckets without earthworms indicates that earthworms may even have a positive influence on the survival of $A$. suum. Wharton (1979) showed that eggs of $A$. suum lost water and collapsed when exposed to air of low relative humidity $(\mathrm{RH})$. Even at the withering point, the RH of air in soil is higher than the RH of the atmosphere above ground (98\% versus $75 \%-92 \%$ in Denmark, Nielsen (1971)). Due to the extreme difference in the surface: volume ratio of pig faeces placed on the soil surface and in the soil itself, eggs in faeces deposited on the soil surface will be more exposed to desiccation (low RH, wind) than eggs located in the soil.
Thus, by transferring the eggs from the surface down into the soil, the earthworms may improve parasite survival. This has recently been reported by Larsen (1996) who found more surviving Ascaris eggs when faeces were deposited in soil than when faeces were placed on the soil surface.

The distribution of the eggs to all soil compartments of the buckets (Table 1) reflects the ability of the earthworms to carry the eggs of $A$. suum for some distance. Normally pigs will root and ingest soil (Fries et al. 1982), but many outdoor reared domestic pigs have their rooting behaviour hampered by noserings. While the transport into the soil may favour egg survival, it may also move the eggs out of reach of the potential hosts. However, a recent study (Mizgaj$s k a, 1997$ ) indicates that earthworms can bring living geohelminth eggs back to the surface of the ground with their casts. The combination of 
removing the parasite eggs from the surface and returning them later will have important influence in spreading the parasite in time.

The success of Szelagiewicz-Czosnek (1972) in infecting guinea pigs with $A$. suum by offering them earthworms which had been force-fed with infective $A$. suum eggs could be explained simply by the presence of infective eggs in the intestine of the earthworms and not by the presence of $A$. suum in the body cavity of earthworms. Furthermore, force feeding of earthworms by injecting a suspension of Ascaris eggs into their mouth could damage the wall of the intestinal tract and thereby make it possible for eggs to enter the coelomic cavity where they may sometimes hatch. The present study was designed to avoid these objections by letting earthworms feed ad libitum on faeces containing embryonated $A$. suum eggs and then by washing and transferring earthworms to parasite-free soil twice with intervening washing. According to Seamster (1950) A. suum requires 27 days $\left(19^{\circ} \mathrm{C}\right)$ to reach the motile-embryo stage. Stoll (1933) refers to a study which showed that eggs of $A$. suum need approximately twice the time needed for embryonation to become infective. Thus, the $A$. suum eggs of the present study had more than sufficient time ( 66 days at $18-22^{\circ} \mathrm{C}$ ) to become infective before earthworms started feeding on the faeces in which they were present. Also, each earthworm should have been in contact with an average of about $25000 \mathrm{~A}$. suum eggs over a period of two weeks, and so if $A$. suum were able to use earthworms as paratenic hosts, the number of parasites infecting the pigs of this experiment via earthworms should be expected to be large. However, the finding of single Ascaris larvae in the small intestines and single white spots on livers in the pigs fed with earthworms as well as in the control pigs suggests an uncontrolled contamination of the pens rather than a infection through earthworms.
In conclusion - the practically complete lack of A. suum in the pigs in combination with the lack of $A$. suum larvae within the dissected earthworms strongly suggests that $A$. longa does not function as a paratenic host of $A$. suum, or at least not under the environmental and other conditions of these studies.

However, the feeding of $A$. longa on faeces containing $A$. suum seems to have a positive effect on the survival and the temporal distribution of A. suum.

Possibly the uptake of infective eggs from deeper soil levels can be reduced by the use of nose-rings. This approach would also hinder $A$. suum eggs from being buried due to the rooting behaviour of the pigs themselves. However, the problem with earthworms bringing parasite eggs back to the soil surface still remains. Mizgajska (1997) did not give any quantitative data from which the size of this problem can be evaluated, for which reason further studies in that direction would be interesting.

\section{Acknowledgements}

Peter Holter of the University of Copenhagen is kındly acknowledged for his help in 1dentifying the earthworms used in this experiment. This study was supported by The Danısh National Research Foundation.

\section{References}

Eriksen L, Lind P, Nansen P, Roepstorff A, Urban J. Resistance to Ascarls suum in parasite naïve and naturally exposed growers, finishers and sows. Vet. Parasit., 1992. 41, 137-149.

Fries GF, Marrow GS, Snow PA. Soil ingestion by swine as a route of contaminant exposure. Environmental Toxicology and Chemistry, 1982. 1, 201-204

Holter $P$ Effect of dung-beetles (Aphodius spp.) and earthworms on the disappearance of cattle dung. Oikos, 197932 (3), 393-402.

Larsen $M N$. Årstıdsvariation 1 overlevelse og udviklıng for de frie larvestadier af 4 svineparasitter 
på friland. (Seasonal variation in the survival and development of the free-living larval stages of 4 pig-parasites under outdoor conditions). Master Thesis. Department of Population B1ology, Zoological Institute, University of Copenhagen 1996.

Mizgajska $H$ The role of some environmental factors in the contamination of soil with Toxocara spp and other geohelminth eggs. Parasitology International, 46(1), 1997 67-72.

Nielsen $L B$ Jordbundsøkologi (Soll ecology) $\mathrm{P}$ Haase \& Søns Forlag. København 1971.

Roepstorff A, Nansen $P$ The epidemiology, diagnosis and control of helminth parasites of swine. A FAO handbook. FAO, Rome (in press)

Rysavý B Lumbricidae - an important parasitological factor in helminthoses of domestic and wild anımals. Pedobılogia, 1969 9, p 171-174

Seamster AP Developmental studies concerning the eggs of Ascaris lumbricoides var suum The American Midland Naturalıst, 1950 43, 450470.

Slotved H-C, Roepstorff A, Barnes EH, Erlksen L, Nansen $P$ Comparison of two methods for recovering migratıng Ascaris suum larvae from the liver and lungs of pigs J. parasit. 1996. 82, 612615.

Slotved H-C, Barnes EH, Erlksen L, Roepstorff A, Nansen $P, B$ Børn $H$ Use of agar-gel technıque for large scale application to recover Ascaris suum larvae from intestınal contents of pigs. Acta vet. scand. 1997, 38, 207-212.

Stoll NR When are Ascarls eggs infective. J. Parasit. 1933. 20, 126.

Szelaglewicz-Czosnek $M$ The role of the soll fauna in the epizootiology of the pig ascaridosis. II Acta parasit. pol 1972. 20, 173-177

Wharton DA Ascaris sp Water loss during desiccation of embryonatıng eggs Exp. Parasit. 1979. $48,398-406$

\section{Sammendrag}

Interaktioner mellem svineparasitten Ascarls suum og regnormen Aporrectodea longa

Portıoner af svinegødnıng indeholdende embryonerede æg af Ascarts suum blev lagt 1 spande med jord I nogle af disse spande var yderligere tilsat 30 regnorme (Aporrectodea longa). Når regnorme var t1l stede, fortærede de gødnıngen og fordelte æggene 1 jorden uden at påføre æggene synlıg skade Fra dette eksperıment blev 10 regnorme fodret til hver af 10 grise, og yderligere 40 regnorme blev dissekeret Ingen grise blev inficeret med $A$ suum, og ingen $A$ suum larver blev fundet 1 de dissekerede regnorme Dette forsøg indikerer, at $A$ longa $1 \mathrm{kke}$ fungerer som paratenisk vært for $A$ suum, men at regnormen transporterer $A$. suum æg ned 1 jorden fra gødnıng deponeret på jordoverfladen

(Recelved June 22, 1998, accepted July 10, 1998)

Reprınts may be obtained from. H -O. Kraglund, Zoology Sectıon, The Royal Veterınary and Agricultural Un1versity, Thorvaldsensvej 40, DK-1871 Frederiksberg C, Denmark. E-mall hork@kvl.dk, tel: +45 352826 81, fax +4535282670 